\title{
Angka dan Pola Bakteri Penyebab Healthcare-Associated Infections (HAIs) pada Udara di Ruang Intensive Cardiac Care Unit (ICCU) Rumah Sakit Umum Daerah (RSUD) dr. M. Yunus Bengkulu
}

\author{
Putri Santri $^{1}$, Mulyadi ${ }^{2}$, Hilda Taurina ${ }^{1}$ \\ ${ }^{1}$ Fakultas Kedokteran dan Ilmu Kesehatan Universitas Bengkulu, \\ ${ }^{2}$ Departemen Patologi Klinik (RSUD) dr. M. Yunus Bengkulu
}

\begin{abstract}
ABSTRAK
Latar Belakang: Udara yang terkontaminasi mikroorganisme khususnya bakteri dapat menyebabkan Healthcare Associated Infections (HAIs) baik lewat pajanan langsung maupun tidak langsung.Lamanya pajanan terhadap udara yang tercemar berhubungan dengan kasus mortalitas pasien dengan penyakit jantung dan pembuluh darah yang di rawat di ruang Intensive Cardiac Care Unit (ICCU). Udara yang tercemar menjadi salah satu faktor risiko penyebab penyakit kardiovaskular yang dapat dimodifikasi.

Metode: Penelitian ini dilakukan dengan cara mengambil sampel dari udara ruang ICCU dengan cara meletakkan lima media cawan petri berisi nutrient agarpada ke empat sudut ruang dan satu posisi di tengah. Sampel kemudian diinkubasi selama 48 jam dan dilakukan penghitungan angka bakteri. Bakteri kemudian dimurnikan, hasil pemurniandilakukan uji pewarnaan gram, uji motilitas, dan uji biokimia untuk mendapatkan pola bakteri.

Hasil: Hasil perletakan cawan petri pada total ke-5 titik sampel adalah $123,6 \times 10^{3} \mathrm{CFU} / \mathrm{m}^{3}$. Total bakteri pada setiap titik adalah sebanyak $36,44 \times 10^{3} \mathrm{CFU} / \mathrm{m}^{3}, 18,21 \times 10^{3} \mathrm{CFU} / \mathrm{m}^{3}, 13 \times 10^{3} \mathrm{CFU} / \mathrm{m}^{3}, 18,21 \times 10^{3} \mathrm{CFU} / \mathrm{m}^{3}$, $37,74 \times 10^{3} \mathrm{CFU} / \mathrm{m}^{3}$ secara berurutan. Hasil pola bakteri didominasi oleh bakteri dari golongan kokus Gram positif yaitu jenis Acinetobacter (a) sebesar 22\%, diikuti bakteri jenis Bacillus (a) 18\%, Kurthia 14\%,Pseudomonas $8 \%$, serta Clostridium, Bacteroides, dan Campylobacter sebanyak 6\%, diikuti Arcobacter dan Staphylococcus 4\%, kemudian Acinetobacter (b), Enterobacteria, Enterococcus, Haemophillus, Streptobacillus dan Streptococcus sebanyak 2\%.

Kesimpulan:Berdasarkan acuan nilai normal jumlah bakteri yaitu $200 \mathrm{CFU} / \mathrm{m}^{3}$, bakteri yang ditemukan pada udara di ruang ICCU melebihi batas normal, sedangkan untuk pola bakteri didominasi oleh bakteri genus Acinetobacter(a)

Kata Kunci : Healthcare Asociated Infections (HAIs), Intensive Cardiac Care Unit (ICCU), angka bakteri, pola bakteri.

\section{Number and Pattern of Aerosol Bacteria Causing Healthcare-Associated Infections (HAIs) in the Intensive Cardiac Care Unit (ICCU) of dr. M. Yunus Regional General Hospital Bengkulu}

\begin{abstract}
Background: The quality of air that been contaminated by microorganism can cause Healthcare Associated Infections (HAIs). Unqualified air has well proven that it is associated with mortality cases of patient with cardiovascular disease that treated in Intensive Cardiac Care Unit (ICCU). Contaminated air is one of modified risk factors that cause cardiovascular diseases.

Method: The research was conducted by taking samples from the air by using passive sampling method. Five dishes with nutrient agar inside placed for 1 hour, $1 \mathrm{~m}$ above the floor and $1 \mathrm{~m}$ away from dangerous materials inside the ICCU of dr. M. Yunus Regional General Hospital Bengkulu. The samples were incubated for 48 hours and then the bacteria was counted and proceed to purity step. After that, the bacteria proceed to the gram staining test, motility test, and biochemical test to find out the pattern of bacteria.

Results: Based on the settle plate on the five points in ICCU, the total number of bacteria were $123.6 \mathrm{x}$ $10^{3} \mathrm{CFU} / \mathrm{m}^{3}$. On the first point $36.44 \times 10^{3} \mathrm{CFU} / \mathrm{m}^{3}, 18.21 \times 10^{3} \mathrm{CFU} / \mathrm{m}^{3}, 13 \times 10^{3} \mathrm{CFU} / \mathrm{m}^{3}, 18.21 \times 10^{3}$ $\mathrm{CFU} / \mathrm{m}^{3}, 37.74 \times 10^{3} \mathrm{CFU} / \mathrm{m}^{3}$ concecutively. The pattern of the bacteria dominated by coccus and positive Gram genus of Bacteria which is Acinetobacter (a) with the percentage was $22 \%$, followed by Bacillus (a) for $18 \%$, Kurthia 14\%,Pseudomonas 8\%, then Clostridium, Bacteroides, and Campylobacter for 6\%, followed by
\end{abstract}


Arcobacter and Staphylococcus for 4\%, thenAcinetobacter (b), Enterobacteria, Enterococcus, Haemophillus, Streptobacillus and Streptococcus for $2 \%$.

Conclusion: Based on the standard number of bacteria in Intensive Cardiac Care Unit, it passed the limit number which is $200 \mathrm{CFU} / \mathrm{m}^{3}$. The pattern of bacteria dominated by Acinetobacter (a).

Keywords: Healthcare Associated Infections (HAIs), Intensive Cardiac Care Unit (ICCU), Number of Bacteria, Pattern of Bacteria

Pendahuluan

Infeksi yang didapat di rumah sakit atau

\section{Healthcare-Associated Infections (HAIs) menurut}

Center for Disease Control and Prevention adalah

kondisi sistemik atau terlokalisir yang merupakan

reaksi efek samping dari pajanan agen infeksius

atau racun yang muncul tanpa adanya bukti bahwa

infeksi tersebut ada atau dalam masa inkubasi saat

pasien masuk ke ruang rawat intensif (CDC, 2016).

Bakteri yang biasanya terlibat dalam penyakit HAIs

termasuk Streptococcusspp, Acinetobacterspp,

Enterococci, Pseudomonas aeruginosa,

Staphylococcus koagulase negatif, Staphylococcus

aureus, Bacillus cereus, Legionella, dan kelompok

Enterobacteriaceae yaitu Proteus mirabilis,

Klebsiella pneumonia, Escherichia coli, dan

Serratia marcescens. Pseudomonas aeruginosa,

Staphylococcus aureus, dan Escherichia coli

memegang peran utama sebagai penyebab HAIs. ${ }^{1}$

Udara yang terkontaminasi

mikroorganisme dapat menyebabkan infeksi yang didapat di rumah sakit (HAIs) baik lewat pajanan

langsung maupun tidak langsung ${ }^{2}$. Bakteri yang

terdapat pada sirkulasi udara di ruangan rumah

sakit dapat berasal dari berbagai sumber baik dari

material biologis maupun non biologis seperti debu.

Ukuran bakteri yang diameternya sekitar 0,3-10 $\mu \mathrm{m}$

memungkinkan bakteri untuk menetap di sirkulasi

udara, bersifat infeksius, dan mengendap di ruangan

dalam jangka waktu yang lama. Ruangan di rumah

sakit dengan suhu yang rendah juga memungkinkan

beberapa bakteri tertentu dapat bertahan lebih lama. $^{3}$

Lamanya pajanan terhadap udara yang tercemar berhubungan dengan kasus mortalitas pasien dengan penyakit jantung dan pembuluh darah yang di rawat di ruang ICCU. ${ }^{4}$ Hubungan yang paling relevan adalah adanya induksi stress oksidatif yang menyebabkan inflamasi sistemik, disfungsi endotelial, atherotrombosis dan arryhytmogenesis yang memperparah keadaan pasien dengan penyakit kardiovaskular..$^{5}$ Udara 
yang tercemar harus diteliti lebih lanjut karena menjadi salah satu faktor risiko penyebab penyakit kardiovaskular yang dapat dimodifikasi. ${ }^{6}$

Berdasarkan uraian di atas, peneliti berkeinginan untuk dapat melakukan penelitian mengenai angka dan pola bakteri pada udara di ruang Intensive Cardiac Care Unit (ICCU) Rumah Sakit Umum Daerah (RSUD) dr. M. Yunus Bengkulu sehingga output yang berupa data angka dan pola bakteri yang akan menjadi acuan pihak rumah sakit untuk dapat mencanangkan program kebersihan lingkungan rumah sakit yang lebih baik

\section{Metode}

Jenis penelitian ini adalah observasional dan menggunakan metode penelitian studi deskriptif laboratorium untuk mengetahui angka dan pola bakteri pada udara dengan menggunakan metodePassive Sampling.Sampel penelitian ini adalah koloni bakteri yang berasal dari hasil peletakan cawan petri yang telah berisi Nutrient Agar (NA) yang diletakkan selama 1 jam, $1 \mathrm{~m}$ di atas lantai dan $1 \mathrm{~m}$ dari benda yang berbahaya di ruang Intensive Cardiac Care Unit (ICCU) RSUD dr. M. Yunus Bengkulu
Kriteria inklusi pada penelitian ini adalahkoloni bakteri yang tumbuh pada cawan petri yang ditempatkan di ruang ICCU RSUD dr. M.Yunus Bengkulu saat dilakukan penelitian pada bulan Desember 2017-Januari 2018. Kriteria eksklusi adalahadanya pertumbuhan mikroorganisme selain bakteri seperti jamur pada media pembiakan sampel. Teknik pengambilan sampel yang digunakan adalah passive sampling dengan cara meletakkan cawan petri pada 5 titik dalam ruangan ICCU RSUD dr. M.Yunus Bengkulu. Sebelumnya peneliti telah membuat media nutrient agar terlebih dahulu sebanyak 25 cawan petri. Kemudian pada ruang ICCU, ditentukan titik tempat meletakkan cawan petri, setelah didapatkan kemudian diletakkan 5 buah cawan petri pada masing-masing titik tersebut, sehingga total media yang diletakkan berjumlah 25 cawan petri. Setelah 1 jam, sampel diambil dan dibawa ke laboratorium mikrobiologi FKIK UNIB untuk diinkubasi selama 48 jam. Setelah diinkubasi, dilakukan proses perhitungan jumlah koloni bakteri. Setelah itu, koloni bakteri dimurnikan dan ditanam di agar miring untuk dilakukan berbagai uji 
biokimia yang bertujuan untuk mengidentifikasi jenis bakteri. Variabel bebas dalam penelitian ini adalahudara di ruang ICCU RSUD dr. M. Yunus Bengkuludan variabel terikat adalah angka dan pola bakteri di ruangan ICCU RSUD dr. M. Yunus Bengkulu.

Alat yang digunakan dalam penelitian ini yaitu handscoon, masker, bunsen, kotak pembawa spesimen, tisu, kertas wrapping, kertas buram, ose, karet, cawan petri, penjepit, kertas label, mikroskop, kaca objek, rak pewarnaan, pipet tetes, vortex, gelas kimia, gelas ukur, plastik tebal, spatula, timbangan analitik, labu erlenmayer, magnetic stirrer, hot plate, autoklaf, dan inkubator, dan bahan yang dibutuhkan adalah spesimen yang Tabel 1. Tabel hitung koloni sampel udara berasal dari udara, aquadest, media Nutrient Agar (NA), safranin, alkohol 95\%, kristal violet, minyak imersi, pati, glukosa $1 \%$, laktosa $1 \%$, sukrosa $1 \%$, nutrient broth, phenol red atau bromkresol ungu, dan reagen hidrogen peroksida $\left(\mathrm{H}_{2} \mathrm{O}_{2}\right) 3 \%$.

\section{Hasil}

\section{Angka Bakteri}

Tabel menunjukkan hasil perhitungan bakteri yang ditemukan dalam satu cawan petri setelah melalui proses inkubasi. Jumlah bakteri tersebut belum menunjukkan jumlah bakteri dalam satuan $\mathrm{CFU} / \mathrm{m}^{3}$, sehingga dilakukan perhitungan berdasarkan metode Koch yang digunakan untuk menghitung jumlah bakteri yang diambil dari sampel udara.

Titik Sampel

\begin{tabular}{cccccc} 
Media Agar & $(1)$ & $(2)$ & $(3)$ & $(4)$ & $(5)$ \\
\hline$(1)$ & 8 koloni & 1 koloni & 3 koloni & 3 koloni & 1 koloni \\
$(2)$ & 11 koloni & 7 koloni & 1 koloni & 5 koloni & 16 koloni \\
$(3)$ & $3 \mathrm{koloni}$ & $1 \mathrm{koloni}$ & $3 \mathrm{koloni}$ & $3 \mathrm{koloni}$ & $9 \mathrm{koloni}$ \\
$(4)$ & $5 \mathrm{koloni}$ & $1 \mathrm{koloni}$ & $2 \mathrm{koloni}$ & $2 \mathrm{koloni}$ & $2 \mathrm{koloni}$ \\
$(5)$ & $1 \mathrm{koloni}$ & $4 \mathrm{koloni}$ & $1 \mathrm{koloni}$ & $1 \mathrm{koloni}$ & $1 \mathrm{koloni}$ \\
Total & $28 \mathrm{koloni}$ & 14 koloni & $10 \mathrm{koloni}$ & 14 koloni & $29 \mathrm{koloni}$ \\
\hline
\end{tabular}

Tabel 2 menunjukkan hasil perhitungan jumlah bakteri (CFU) berdasarkan metode Koch (Badea et al., 2015; Bhatia dan Vishwakarma, 2011) ${ }^{7,8}$ yaitu: $\quad \mathrm{CFU} / \mathrm{m}^{3}=$ a.10000/p.t.0,2

\section{Keterangan:}

$\mathrm{a}=$ Jumlah koloni bakteri di cawan petri

$\mathrm{p}=$ Luas permukaan cawan petri

$\mathrm{t}=$ waktu peletakan cawan petri (dalam menit) 
Untuk mendapatkan jumlah bakteri dalam satuan

$\mathrm{CFU} / \mathrm{m}^{3}$, diperlukan nilai a yaitu jumlah koloni

bakteri di cawan petri (tabel 4.1), nilai p yaitu luas permukaan cawan petri yang digunakan sebesar 1 $\mathrm{m}^{2}$, dan nilai $\mathrm{t}$ yaitu waktu peletakan cawan petri

dalam 60 menit

Tabel 2.Tabel hitung koloni sampel udara dalam

$\mathrm{CFU} / \mathrm{m}^{3}$

Media

\begin{tabular}{cccccc} 
& $(1)^{*}$ & $(2)^{*}$ & $(3)^{*}$ & $(4)^{*}$ & $(5)^{*}$ \\
\hline$(1)$ & 10,41 & 1,30 & 3,90 & 3,90 & 1,30 \\
$(2)$ & 14,32 & 9,11 & 1,30 & 6,51 & 20,83 \\
$(3)$ & 3,90 & 1,30 & 3,90 & 3,90 & 11,71 \\
$(4)$ & 6,51 & 1,30 & 2,60 & 2,60 & 2,60 \\
$(5)$ & 1,30 & 5,20 & 1,30 & 1,30 & 1,30 \\
Jumlah & 36,44 & 18,21 & 13 & 18,21 & 37,74 \\
Total & 123,6 & & & & \\
\hline
\end{tabular}

\section{Identifikasi Pewarnaan Gram Bakteri}

Hasil pewarnaan gram didapatkan bakteri yang termasuk ke dalam kategori gram positif kokkus sebanyak 18 isolat, bakteri gram positif

Tabel 3.Pewarnaan Gram

\begin{tabular}{cccccc}
\hline $\begin{array}{c}\text { Katego } \\
\text { ri } \\
\text { Isolat }\end{array}$ & $\begin{array}{c}\text { Gram } \\
(+) \\
\text { Kokku } \\
\mathrm{s}\end{array}$ & $\begin{array}{c}\text { Gram } \\
(+) \\
\text { Basil }\end{array}$ & $\begin{array}{c}\text { Gram (-) } \\
\text { Kokkus }\end{array}$ & $\begin{array}{c}\text { Gram } \\
(-) \\
\text { Basil }\end{array}$ & $\begin{array}{c}\text { Total } \\
\text { Isolat }\end{array}$ \\
\hline Udara & 18 & 16 & 9 & 7 & 50 \\
\hline
\end{tabular}

\section{Hasil Uji Motilitas}

Uji motilitas bakteri dilakukan untuk

kemampuan bakteri dalam bergerak atau bersifat

motil. Bakteri bersifat motil ditandai dengan adanya

pertumbuhan menyebar di daerah sekitar tusukan

ose, sedangkan bakteri non motil ditandai tidak

adamya penyebaran bakteri di daerah sekitar

tusukan ose. Dari hasil uji motilitas, didapatkan basil sebanyak 16 isolat, sedangkan bakteri gram negatif kokkus sebanyak 9 isolat, dan bakteri gram negatif basil sebanyak 7 isolat.

bahwa isolat bakteri yang positif didapatkan sebanyak 28 bakteri (56\%), sedangkan isolat bakteri dengan hasil negatif sebanyak 22 isolat bakteri $(44 \%)$.

\section{Hasil Uji Biokimia}

Uji biokimia terdiri dari uji fermentasi karbohidrat, uji katalase, dan uji hidrolisis pati. Uji fermentasi karbohidrat bertujuan untuk dapat melihat kemampuan bakteri dalam memfermentasi karbohidrat berupa glukosa, sukrosa, dan laktosa. Uji fermentasi karbohidrat positif ditandai dengan perubahan warna phenol redatau bromkresol ungu 
menjadi kekuningan, sedangkan uji fermentasi karbohidrat negatif ditandai dengan tidak adanya perubahan warna.

\section{Uji Fermentasi Karbohidrat}

Isolat bakteri yang bernilai positif untuk uji karbohidrat didapatkan sebanyak 18 isolat bakteri (36\%), sedangkan yang bernilai negatif didapatkan sebanyak 32 isolat bakteri (64\%).

\section{Uji Katalase}

Uji katalase merupakan uji yang dilakukan pada isolat bakteri untuk menilai apakah bakteri dapat mengkatalis $\mathrm{H}_{2} \mathrm{O}_{2}$ menjadi air $\left(\mathrm{H}_{2} \mathrm{O}\right)$ dan Oksigen $\left(\mathrm{O}_{2}\right)$. Enzim ini bertujuan untukk mencegah oksidasi hidrogen peroksida yang dapat merusak dan membunuh bakteri. Uji katalase bernilai positif ditandai dengan adanya buih atau gelembung-gelembung air setelah bakteri ditetesi dnegan hidrogen peroksida $\left(\mathrm{H}_{2} \mathrm{O}_{2}\right)$ Uji katalase bernilai negatif ditandai dengan tidak adanya buih atau gelembung-gelembung air pada saat bakteri ditetesi dengan hidrogen peroksida $\left(\mathrm{H}_{2} \mathrm{O}_{2}\right)$. Berdasarkan hasil uji, didapatkan isolat bakteri yang bernilai positif sebanyak 38 isolat bakteri
(76\%), sedangkan bakteri dengan hasil negatif didapatkan sebanyak 12 isolat bakteri (24\%).

\section{Uji Hidrolisis Pati}

Uji hidrolisis pati bertujuan unntuk mengidentifikasi bakteri yang memiliki kemampuan untuk dapat melisiskan pati saat diteteskan iodin. Uji hidrolisis pati positif ditandai dengan adanya zona bening pada agar yang di dalamnya telah dibiakkan bakteri dan diinkubasi selama 24 jam, kemudian bakteri yang tumbuh ditetesi oleh iodin. Uji hidrolisis pati negatif ditandai dengan tidak terdapatnya zona bening pada bakteri yang tumbuh di agar. Dari hasil uji hidrolisi pati yang dilakukan pada sampel bakteri, didapatkan hasil positif sebanyak 39 isolat bakteri (78\%), sedangkan hasil negatif didapatkan sebanyak 11 isolat bakteri (22\%).

\section{Pola Bakteri pada Udara di Ruang Intensive}

\section{Cardiac Care Unit (ICCU) RSUD dr. M. Yunus}

\section{Bengkulu}

Berdasarkan hasil pewarnaan Gram, uji motilitas dan uji biokimia yang telah dilakukan didapatkan hasil pada sampel udara di ruang ICCU RSUD Dr. M. Yunus Bengkulu, genus bakteri yang 
didapatkan setelah disesuaikan dengan tabel acuan genus bakteri, didapatkan genus bakteri yang sangat bervariasi. Persentase terbesar dari bakteri yang didapatkan pada sampel udara di ruang ICCU RSUD dr M.Yunus Bengkulu adalah bakteri Acinetobacter (a) yaitu sebesar 22\%. Pasien dengan sistem imun yang lemah, memiliki penyakit paru kronik, atau diabetes dapat lebih rentan terkena penyakit infeksi yang disebabkan oleh bakteri ini. Pasien yang dirawat di rumah sakit, khususnya pasien dengan ventilator serta telah dirawat dalam waktu yang lama, memilki luka terbuka, atau pasien dengan tindakan invasif seperti pemasangan kateter urin memiliki risiko yang lebih besar untuk terkena Healthcare Associated Infections (HAIs) akibat Acinetobacter. ${ }^{9}$

Acinetobacter menjadi bakteri yang paling mendominasi pada penelitian ini, sesuai dengan studi yang dilakukan oleh Obeid at et al (2014) yang menyimpulkan bahwa semua strain Acinetobacter dapat bertahan dengan baik di lingkungan rumah sakit, terutama di lingkungan berair dan lembab yang dapat menghasilkan biofilm. Hal tersebut mendasari tingginya kolonisasi Acinetobacter padasaluran pernapasan pasien di ruang rawat intensif. ${ }^{10}$ Pola genus bakteri yang lain seperti pada gambar berikut:

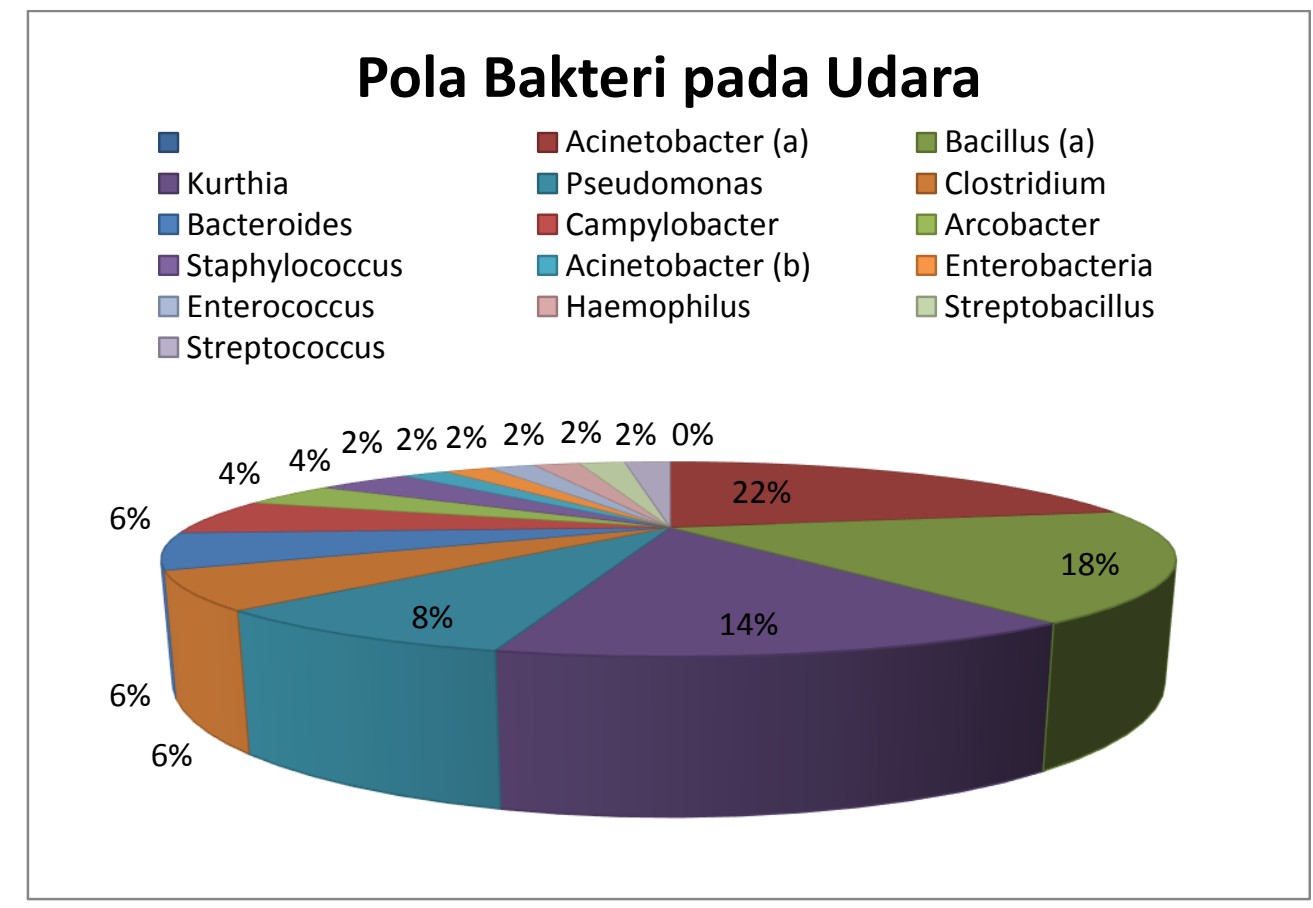

Gambar 1. Pola Bakteri pada Udara 


\section{Pembahasan}

\section{Angka Bakteri}

Berdasarkan hasil penghitungan untuk jumlah bakteri, total keseluruhan bakteri pada udara di ruang ICCU didapatkan jumlah bakteri secara sebanyak $2.433,6 \mathrm{CFU} / \mathrm{m}^{3}$, rata-rata jumlah bakteri yaitu 488,72 $\mathrm{CFU} / \mathrm{m}^{3}$ pada setiap titik dengan titik terbanyak terdapat pada titik sampel ke 5 media ke 2 yaitu sebanyak 16 koloni dengan hasil konversi pada perhitungan $\mathrm{CFU} / \mathrm{m}^{3}$ yaitu sebanyak $374,4 \mathrm{CFU} / \mathrm{m}^{3}$.

Sumber munculnya mikroorganisme patogen di udara adalah hasil penularan dari pasien yang dicurigai memiliki penyakit infeksi dan kemudian mikroorganisme penyebab infeksi tersebut menyebar melalui udara. Mekanisme yang diduga kuat menyumbang penyebaran mikroorganisme patogen di udara adalah berasal dari produksi droplet aerosol seperti dari aktivitas bersin dan batuk, serta dengan kandungan air yang sedikit, memungkinkan patogen dapat bertahan dalam jangka waktu yang lama. Dalam keadaan klinis tertentu, lesi pada kulit juga dapat menjadi sumber partikel di udara yang bersifat patogen. ${ }^{13}$
Bakteri yang terdapat pada sirkulasi udara di ruangan rumah sakit dapat berasal dari berbagai sumber baik dari material biologis maupun non biologis seperti debu. Ukuran bakteri yang diameternya sekitar $0,3-10 \quad \mu \mathrm{m}$ memungkinkan bakteri untuk menetap di sirkulasi udara, bersifat infeksius, dan mengendap di ruangan dalam jangka waktu yang lama. Ruangan di rumah sakit dengan suhu yang rendah juga memungkinkan beberapa bakteri tertentu dapat bertahan lebih lama. ${ }^{14}$

\section{Ruang Intensive Cardiac Care Unit}

(ICCU) RSUD Dr. M. Yunus Bengkulu memiliki kemungkinan kejadian HAIs, hal ini disebabkan oleh tingginya angka bakteri pada kategori udara yang melebihi batas normal yang ditetapkan PERMENKES. Berdasarkan latar belakang penelitian yang merujuk kepada batas normal angka bakteri yang ditetapkan PERMENKES pada ruang Intensive Cardiac Care Unit (ICCU) dalam menjamin kualitas udara di dalamnya, konsentrasi maksimum mikroorganisme adalah $200 \mathrm{CFU} / \mathrm{m}^{3}$, suhu $22-23^{\circ}$, kelembaban $35-60 \%$, dan tekanan positif. ${ }^{15}$ Kualitas udara di lingkungan rumah sakit 
merupakan salah satu hal yang harus menjadi fokus perhatian, hal itu dikarenakan pasien dengan penyakit infeksi di rumah sakit memungkinkan untuk menjadi sumber penularan penyakit akibat banyaknya mikroorganisme. ${ }^{16}$

\section{Pola Bakteri}

Identifikasi pola bakteri dilakukan dengan pemeriksaan pewarnaan Gram, uji motilitas dan uji biokimia yang terdiri dari uji fermentasi karbohidrat, uji hidrolisis pati dan uji katalase. Identifikasi bakteri yang pertama dilakukan adalah pewarnaan Gram. Berdasarkan hasil identifikasi pola bakteri yang dilakukan di ruang Intensive Cardiac Care Unit (ICCU) RSUD Dr. M. Yunus dengan pengambilan sampel yang berasal dari udara, menunjukkan bahwa pola bakteri didominasi oleh bakteri dari golongan kokus Gram positif yaitu jenis Acinetobacter sebesar $22 \%$.

Tiga jenis bakteri yang mendomiasi dimulai dari urutan pertama adalah bakteri jenis Acinetobacter (a) sebesar $22 \%$, diikuti dengan bakteri jenis Bacillus (a) sebanyak 18\%, dan kemudian diikuti jenis bakteri Kurthia sebanyak 14\%. Penelitian angka dan pola bakteri juga dilakukan di ruang Intensive Care Unit (ICU)

RSUD dr. M. Yunus Bengkulu, dari penghitungan 30 sampel yang diambil dari dinding, lantai, dan peralatan medis, didapatkan bakteri dengan jumlah terbanyak berasal dari genus Enterobacter sebesar $32 \% .^{17}$

Genus Acinetobacter merupakan genus bakteri yang mendominasi pola bakteri di ruang ICCU RSUD Dr. M. Yunus Bengkulu. Acinetobacter (a) merupakan genus bakteri yang terdiri dari Acinetobacter (a) dan (b). Acinetobacter (a) merupakan jenis bakteri dengan morfologi berbentuk kokus, hasil pewarnaan menunjukkan bakteri gram positif, dengan uji katalase positif, namun uji motilitas serta uji fermentasi karbohidrat menunjukkan hasil negatif. Acinetobacter (b) merupakan jenis bakteri dengan morfologi dan hasil uji yang hampir sama dengan Acinetobacter (a), perbedaannya terletak pada hasil pewarnaan gram, yaitu Acinetobacter (b) menunjukkan hasil negatif pada pewarnaan gram. ${ }^{18}$ Bakteri genus Acinetobacter dapat menyebabkan berbagai jenis penyakit, mulai dari pneumonia sampai penyakit infeksi serius pada luka dan darah 
dengan gejala yang muncul dapat bervariasi, tergantung kepada jenis penyakitnya.

Bakteri terbanyak kedua dari hasil isolasi sampel udara di ruang ICCU RSUD dr M. Yuus Bengkulu dengan persentase bakteri sebanyak $18 \%$ adalah genus Bacillus. Bacillus merupakan bakteri berbentuk batang Gram positif, Bakteri genus Bacillus dapat beradaptasi pada perubahan suhu lingkungan dan zat kimia dengan membentuk endospora. Bacillus merupakan flora normal di tanah, udara, air dan kompos tanah (Rahmaningsih et al., 2012). ${ }^{19}$ Bakteri ini sering menjadi penyebab keracunan makanan dengan manifestasi klinis onset cepat berupa muntah dan diare. Bacillus subtilis dapat menimbulkan penyakit seperti meningitis, endocarditis, endoftalmitis dan gastroenteritis pada pasien dengan imunocompromise. ${ }^{20}$

Kurthia merupakan genus bakteri ketiga yang paling banyak ditemukan di udara, bakteri ini berukuran sekitar 0,8-1,2 mikrometer, berbentuk basil dengan kemampuan bakteri yang dapat bergerak (motil) karena memiliki flagel. Umumnya, bakteri genus Kurthia bukan merupakan bakteri yang bersifat patogen. Jenis bakteri ini dapat ditemukan di berbagai peralatan medis, namun umumnya Kurthia berasal dari feses pasien yang didiagnosis diare.

Berdasarkan hasil penelitian yang telah dilakukan, Healthare Associated Infections (HAIs) mungkin terjadi pada ruang ICCU RSUD Dr. M. Yunus Bengkulu dikarenakan hasil dari jumlah total isolasi bakteri yang melebihi nilai normal yang telah ditetapkan berdasarkan PERMENKES 2016 yaitu $200 \mathrm{CFU} / \mathrm{m}^{3}$.

\section{Keterbatasan Penelitian}

Keterbatasan dalam penelitian ini adalahpenelitian ini sangat membutuhkan peralatan yang steril dan metode yang menuntut ketelitian. Peralatan yang digunakan terkadang masih belum steril, sehingga perlu dilakukan beberapa kali pengulangan proses sterilisasi saat penelitian berlangsung. Selain itu, penelitian ini juga menggunakan biaya yang tidak sedikit karena bahan yang diperlukan cukup banyak.

\section{Kesimpulan}

1. Angka bakteri yang didapatkan dari 5 titik sampel dengan 5 media cawan petri yang 
diletakkan pada setiap titik, didapatkan total koloni sebanyak $123,6 \times 10^{3} \mathrm{CFU} / \mathrm{m}^{3}$.

2. Hasil Pewarnaan Gram,didapatkan bakteri yang termasuk ke dalam kategori Gram positif kokus sebanyak 18 isolat, bakteri Gram positif basil sebanyak 16 isolat, sedangkan bakteri Gram negatif kokus sebanyak 9 isolat, dan bakteri Gram negatif basil sebanyak 7 isolat.

3. Hasil Identifikasi Pola Bakteri:

a. Uji Fermentasi karbohidrat:

Isolat bakteri yang bernilai positif untuk uji karbohidrat didapatkan sebanyak 18 isolat bakteri, sedangkan yang bernilai negatif didapatkan sebanyak 32 isolat bakteri.

b. Uji katalase:

Isolat bakteri yang bernilai positif sebanyak 38 isolat bakteri, sedangkan bakteri dengan hasil negatif didapatkan sebanyak 12 isolat bakteri.

c. Uji motilitas:

Isolat bakteri yang positif didapatkan sebanyak 28 bakteri, sedangkan isolat bakteri dengan hasil negatif sebanyak 22 isolat.

d. Uji hidrolisis pati didapatkan hasil positif sebanyak 39 isolat bakteri, sedangkan hasil negatif didapatkan sebanyak 11 isolat bakteri

4. Persentase masing-masing jenis bakteri:

Bakteri Acinetobacter(a) sebesar 22\%, Bacillus (a) sebanyak 18\%, Kurthia sebanyak 14\%,Pseudomonas $8 \%$, serta Clostridium, Bacteroides, dan Campylobacter sebanyak 6\%, diikuti Arcobacter dan Staphylococcus sebanyak 4\%, kemudian Acinetobacter (b), Enterobacteria, Enterococcus, Haemophillus, Streptobacillus dan Streptococcus sebanyak $2 \%$.

\section{Daftar Pustaka}

1. Khan, H.A., Ahmad, A., Mehboob, R., 2015. Asian Pacific Journal of Tropical Biomedicine. Nosocomial Infections and Their Control Strategies, [online] Available at: $\underline{\text { www.elsevier.com/locate/apjtb }}$ [Accessed March 14 2017]. 
2. Goering, R.V., Dockrell, H.M., Zuckerman, M., Roitt, I.M., Chiodini, P.L., 2013. Mim’s Medical Microbiology, Fifth Edition. The McGraw- Hill Companies, USA.

3. Fernstrom, A., Goldblatt, M., 2013. Aerobiology and Its Role in the Transmission of Infectious Diseases. USA: J of Pathogen. Available at: http://dx.doi.org/10.1155/2013/493960

[Accessed June 20 2017].

4. Pope, C.A., Burnett, R.T., Thurston, G.D., Thun, M.J., Calle, E.E., Krewski, D., et al., 2004. Cardiovascular Mortality and LongTerm Exposure to Particulate Air Pollution Epidemiological Evidence of General Pathophysiological Pathways of Disease. American Heart Association. Available at: http://circ.ahajournals.org/ [Accessed July 12 2017].

5. Mills, N.L., Miller, M.R., Lucking, A.J.,Beveridge, J.,Flint, L., Boere, A.J., et al., 2011. Combustion-derived nanoparticulate mediates the adverse vascular effects of diesel exhaustinhalation. Available at: https://www.ncbi.nlm.nih.gov/pubmed/21753 226 [Accessed May 19 2017].

6. Newby, D.E., Mannucci, P.M., Tell, G.S., Baccarelli, A.A., Brook, R.D., Donaldson, K., et al., 2015. Expert Position Paper on Air Pollution and Cardiovascular Disease. Europe Eur Heart J Cardiovasc. Available at: https://academic.oup.com/eurheartj/article/36 /2/83/2293343/Expert-position-paper-on-airpollution-and-cardio-vascular-disease [Accessed May 19 2017].

7. Badea, S., Chirita, A.L., Androne, C., Olaru, B.G., 2015. Indoor air Quality Assesment Through Microbiological Methods. Romania: Y. Sci. J. Available at:http://journalofyoungscientist.usamv.ro/pdf /vol_III_2015/art1.pdf [Accessed June 14 2017].

8. Bhatia, L., dan Vishwakarma R., 2011. Hospital Indoor Airborne Microflora in Private and Government Owned Hospitals in Sagar City. India: J Environ manage.Available at:http://www.ugcfrp.ac.in/images/userfiles/ij 
eemv2n1_8 5141_Corrected\%20file\%20(2).

pdf [Accessd June 16 2017].

9. Center for Disease Control and Prevention. Healthcare-Associated Infections: HAI Data and Statistic. USA: Center for Disease Control and Prevention; 2010.

10. Obeidat, N., Jawdat F., Al Bakri, A.G., Shehabi, A.A., 2014. Am J Infect Control. Major biologic characteristics of Acinetobacter baumannii isolates from hospital environmental and patients' respiratory tract sources. Available at: https://www.ncbi.nlm.nih.gov/pubmed/24679 567 [Accessed May 29 2018].

11. Hasana, N.M.N.A., Rares, F.E.S., Porotu'o, J., 2017. Isolasi dan identifikasi bakteri aerob yang dapat meyebabkan infeksi nosokomial di Ruang Bedah Mata RSUP Prof. Dr. R. D. Kondou Manado. Skripsi. Fakultas Kedokteran Universitas Sam Ratulangi Manado.

12. Oktarini, M., 2013. Angka dan pola kuman pada dinding, lantai dan udara di ruang ICU RSUD dr. Moewardi surakarta. Skripsi.
Fakultas Kedokteran Universitas

Muhammadiyah Surakarta.

13. Tang, J.W., 2009. J R Soc Interface. The effect of environmental parameters on the survival of airborne infectious agents,

Available

at:

https://www.ncbi.nlm.nih.gov/pmc/articles/P

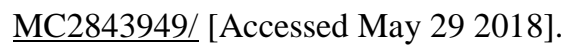

14. Fernstrom, A., Goldblatt, M., 2013. Aerobiology and Its Role in the Transmission of Infectious Diseases. USA: J of Pathogen.

Available

at:

http://dx.doi.org/10.1155/2013/493960

[Accessed June 20 2017].

15. Peraturan Menteri Kesehatan Republik Indonesia Tentang PersyaratanKesehatan Lingkungan Rumah Sakit. 2016 No. 24 Tahun 2016. Jakarta.

16. Quadiset, K., Abu-Elteen, K., Elkarmi, A., Hamad, M. 2009. Assessment of airborne pathogens in health care setting. Afr. J. Microbiol. [Accessed May 29 2018]. 
17. Erickson, T., 2016. Angka dan Pola Bakteri yang Ada di Dinding, Lantai dan Tempat Tidur Pasien di Ruang ICU Rumah Sakit Umum Daerah (RSUD) Dr. M. Yunus Bengkulu. Skripsi. Fakultas Kedokteran dan Ilmu Kesehatan Universitas Bengkulu.

18. Barrow, G., dan Feltham, R., 2004. Cowan and Steels Manual for The Identification of Medical Bacteria. United Kingdom: Cambridge University.

19. Rahmaningsih, S., dan Wilis S., Mulyana. A., 2012. Bakteri Patogen dari Perairan Pantai dan Kawasan Tambak di Kecamatan Jenu Kabupaten Tuban, Ekologia, Vol. 12 No.1 15.

20. Brooks, G.F., Carrol, K.C., Butel, J.S., Morse, S.A., Mietzner, T.A., 2017. Jawetz, Melnick \& Adelberg's Medical Microbiology 25th Edition. United States: The McGrawHill Companies.

21. Center for Disease Control and Prevention. Healthcare-Associated Infections: HAI Data and Statistic. USA: Center for Disease Control and Prevention; 2016. 